\title{
FREE AMINO ACID CONCENTRATION IN HYDATID CYST FLUIDS FROM FERTILE AND INFERTILE HUMAN AND ANIMAL ECHINOCOCCUS GRANULOSUS
}

\author{
ÇELIK C.*, AMANVERMEZ R.** \& ÖZKAN K.**
}

\section{Summary :}

The aim of this study was to search and compare free amino acid composition of fertile and infertile cyst fluids obtained from humans and animals infected naturally with Echinococcus granulosus, by using automated analysis based on cation-exchange

chromatography with post-column ninhydrin derivatization system. 11 free amino acids from fertile (sheep origin), nine from infertile (cattle origin), 13 from infertile (human origin) hydatid cyst fluids and 19 amino acids from sera of patients with hydatid infection were detected. The levels of glycine, alanine, valine and tyrosine in fertile and infertile hydatid cysts fluids were significantly higher than in sera from patients with hydatid cysts.

Glycine level in the fertile hydatid cyst fluids (sheep origin) was significantly higher than those of infertile cysts fluids /cattle and human origin) and sera with hydatid patients. Glycine level in fertile hydatid cyst fluids was about two times more concentrated in infertile cattle cyst fluids, 10 times more concentrated in infertile human hydatid cyst fluids and 13 times more concentrated in sera with hydatid patients. On the other hand, alanine and valine concentration in the fertile and infertile cyst fluids were at similar level with the exception that valine level in fertile cyst fluids was 12 times more concentrated in infertile human cyst fluids. The levels of tyrosine, citrulline, leucine, isoleucine and lysine amino acids in fertile and infertile hydatid cyst fluids were similar.

Our findings with respect to fertile and infertile cysts fluids showed that free amino acids concentrations in cyst fluids were significantly higher in sera from patients with hydatid cyst. Total amount of free amino acids content in fertile and infertile cyst fluids was three to eight times higher from that of human sera with hydatid patients.

KEY WORDS : Echinococcus granulosus, hydatid cyst, hydatid fluid, free amino acids.

$\mathrm{H}$ ydatid disease is still a major parasitic problem in certain areas of the world. It affects human and farm animal health and causes economic loss. Fertile cysts with viable protoscolecces play an effective role in contamination and the life cycle of Echinococcus granulosus.

In the last two decades, carbohydrate, lipid components, nitrogenous, trace elements, electrolyte, dia-

* Department of Biochemistry and,

** General Surgery, Faculty of Medicine, Ondokuz Mayıs University, 55139 Kurupelit/Samsun, Turkey.

Correspondence: Dr Cemil Çelik.

Tel.: 903624575580 - Fax: 903624576041 .

E-mail: ccem61@hotmail.com mental@ omu.edu.tr
Résumé : TAUX DE CONCENTRATIONS EN ACIDES AMINÉS LIBRES DANS DES LIQUIDES DE KYSTES HYDATIQUES FERTILES ET INFERTILES CHEZ DES ANIMAUX ET DES HUMAINS

L'objectif de notre étude était de mesurer et comparer les taux de concentrations des acides aminés libres (AAL) dans des liquides de kystes hydatiques fertiles et infertiles chez des humains et des animaux par une analyse automatisée par chromatographie d'échange de cations utilisant un système de dérivation de postcolonne ninhydrine.

Les taux de 11 AAL dans des kystes fertiles d'origine ovine, de neuf AAL dans des kystes infertiles d'origine bovine, de $13 \mathrm{AAL}$ dans des kystes infertiles d'origine humaine et de 19 AAL dans le plasma des patients infectés ont été mesurés.

Le taux de glycine dans les kystes fertiles d'origine ovine a été trouvé élevé de façon significative par rapport aux taux mesurés dans des liquides kystiques infertiles d'origine bovine (deux fois plus) et d'origine humaine (10 fois plus) ainsi que dans le plasma des patients infectés (13 fois plus).

Les taux de concentrations d'alanine et de valine dans des kystes fertiles d'ovins et infertiles de bovins, étant très proches l'un de l'autre, ont été mesurés 12 fois plus élevés que les taux trouvés dans des kystes infertiles humains.

Les résultats de cette étude montrent que, contrairement aux nombreux métabolites, les taux d'AAL kystiques sont statistiquement plus élevés que les taux plasmatiques humains. L'explication d'une relation directe entre I'AAL dans des liquides kystiques et le métabolisme des protoscolex devient difficile du fait que les taux des autres AAL mesurés, hormis ceux de glycine, dans des kystes fertiles et infertiles sont proches.

MOTS CLÉS : Echinococcus granulosus, kyste hydatique, liquide hydatique, acides aminés libres.

gnostic antigens and vitamine levels, and metabolic site of these parameters were examined in hydatid cyst fluids by different researchers (McManus \& Smyth, 1978; Frayha \& Haddad, 1980; McManus, 1981; Barrett, 1981; Njeruh et al., 1989; Özen et al., 1992). Urea and pyrimidine biosynthesis capacity of protoscolecces and total protein contents in cyst fluids were investigated in different hydatid cysts from human and animals origin (Çelik, 1986, 1987). Chromatographic separations of all methylated basic amino acids and related compounds in alveolar hydatid cyst-induced amyloid protein were also investigated (Alkarmi1 et al., 1986).

There are however few reports on the free amino acid content of cyst fluids of Echinococcus granulosus. Free amino acid pool of Hymenolepis diminuta (Chappell 
\& Walker, 1980), cysticercus of Taenia bydatigena (Pathak et al., 1980) and cyst fluid of Echinococcus granulosus from primary and secondary equine cysts, secondary sheep cysts and host plasma have been examined and compared with HPLC cation-exchange system using fluorescence detector with O-phthaldialdehyde (Hurd, 1989).

In this study, we aimed at searching for the first time free amino acid composition of fertile and infertile cyst fluids of human and animal Echinococcus granulosus with automated analyses based on cation-exchange chromotography with post-column ninhydrin derivatization (HPLC-Pickering Post-Column Amino Acid Analysis) system.

\section{MATERIALS AND METHODS}

\section{SOURCE OF MATERIAL}

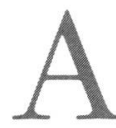
nimal hydatid cyst fluids were obtained from the livers of freshly slaughtered sheep and cattle from local slaughter houses in Samsun, Turkey. Human hydatid cyst fluids and host sera were obtained from General Surgery Department of Academic Hospital, Ondokuz Mayis University, Samsun, Turkey.

Sheep and cattle cyst fluids were aspirated directly from the liver cyst of ten sheep and ten cattle with hydatid disease. Human hydatid cyst fluids of liver were obtained by sterile syringe from three patients with hydatid disease under surgical operation. Sera were also obtained from the same patients during the bed side testing before surgery. Human sera, cyst fluid and animal cyst fluid were collected in metal free tubes. Free amino acid concentration of cyst fluid and human blood sera were freshly analyzed by cation-exchange - HPLC post-column system (Pickering, 1989).

\section{EQUIPMENT AND REAGENTS}

The $3 \mathrm{~mm} \times 150 \mathrm{~mm}$ high-efficiency cation-exchange column, guard column $2 \times 20$ mm, PCX3100 postcolumn derivatization instrument, lithium citrate $\mathrm{pH}$ 2.80 ( $\mathrm{Li} 280$ ) and 7.5 ( $\mathrm{Li} 750$ ) eluents and pH 2.2 diluent, regenerant (RG003), seraprep, uriprep, and ninhydrin were from Pickering Labs (USA). AS 300 Model Spectra System autosampler, Spectra System UV 3000HR Model detector, and PC 1000 Software Computer Programs and Spectra System P400 Gradient Pump were from Thermo Separation Products (USA). Physiological amino acid calibration standard was from Sigma Chemical Co.

\section{SAMPLE PREPARATION FOR CHROMATOGRAPHY}

Fertile hydatid cyst fluids from sheep liver hydatid cysts (n:10) with viable protoscolecces, and infertile hydatid cyst fluids from cattle liver hydatid cysts (n: 10) and liver hydatid fluids (n: 3) and blood sera from patients with hydatid disease (n: 3) were prepared for free amino acid analysis with HPLC post-column derivatization pickering system.

Seraprep (Pickering, USA) was used as the protein precipitation reagent for serum of hydatid disease patients, and Ureprep (Pickering, USA) for all of the hydatid cyst fluid samples. Cysts fluids and sera were placed in a microcentrifuge tube with equal portions of seraprep or ureprep as recommended by the manufacturer. They were let to stand for five minutes prior to centrifugation by Jouan CR 412 model (France) centrifuged at 10,000 rpm for five minutes, and the supernate's $\mathrm{pH}$ was checked with universal-indicator paper (Merck) to ensure the $\mathrm{pH}$ is within the range of $2.3 \pm 0.2$. Supernatant was then filtered using a syringe filter $(0.45 \mathrm{~mm})$ and transferred to auto-sampler assay vials for HPLC analysis.

\section{CHROMATOGRAPHY STEP}

All cyst fluids and blood sera were analysed according to Pickering HPLC Lithium Gradient method (Pickering Laboratories, 1995-1996). Sample injection volume was $5 \mathrm{ml}$. Before, the sample preparation standard amino acids mix (liquid standard from Sigma Chemical Co) was applied to the column, and standard peak identification and integration were obtained.

The column was equilibrated with buffer A lithium eluent ( $\mathrm{Li} \mathrm{pH}$ : 2.80) and gradient procedure was run as a Pickering amino acid analysis method $\left(40^{\circ} \mathrm{C}\right.$ at a flow rate of $0.3 \mathrm{ml} / \mathrm{min}$ for buffers, and $0.3 \mathrm{ml} / \mathrm{min}$ for the ninhydrin). Total assay time was $140 \mathrm{~min}$. The elution of amino acids was monitored at $570 \mathrm{~nm}$.

Results were calculated with PC 1000 software computer program (automatic method) reference to standard amino acids peak integratation. Comparable data were pooled for statistical analysis using Mann Withney U-test.

\section{RESULTS}

L iquid amino acid standards (Sigma) were applied to cation-exchange column as described. Figure 1 standards according to the gradient method as given in Table I. The study materials were similarly run, and the peak integrations and the amount of free amino acids were directly obtained from the computer programme.

The levels of free amino acids in $\mathrm{mmol} / \mathrm{ml}$ in cyst fluids of our study materials are summarised in Table II, and show that the fertile cyst fluids from sheep liver, infertile cattle and human hydatid cyst fluids and serum 
Column: $3 \mathrm{~mm}$ ID $\times 150 \mathrm{~mm}$

Guard : $2 \mathrm{~mm}$ ID x $20 \mathrm{~m}$

Lithium eluent gradient, $\mathrm{pH}$ 2.80-7.50

Detection by TRIONE ninhydrin @ 570nm

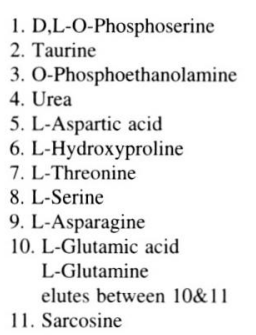

D,L-O-Phosphoserine

3. O-Phosphoethanolamine

4. Urea

5. L-Aspartic acid

L-Hydroxyproline

8. L-Serine

9. L-Asparagine

L-Glutamic aci

elutes betw

11. Sarcosine

\section{PEAK IDENTIFICATION}

$\begin{array}{ll}\text { 12. D,L- } \alpha \text {-Aminoatipic acid } & \text { 25. L-Tyrosine } \\ \text { 13. L-Proline } & \text { 26. L-Phenylalanine } \\ \text { 14. Glycine } & \text { 27. } \beta \text {-Alanine } \\ \text { 15. L-Alanine } & \text { 28. D.L- } \beta \text {-Amino-i-butyric acid } \\ \text { 16. Citrulline } & \text { 29. D.L-Homocystine } \\ \text { 17. L- } \alpha \text {-Amino-n-butyric acid } & \text { 30. } \gamma \text {-Amino butyric acid } \\ \text { 18. L-Valine } & \text { 31. L-Tryptophan } \\ \text { 19. L-Cystine } & \text { 32. Ethanolamine } \\ \text { 20. L-Methionine } & \text { 33. D,L \& allo-Hydroxylysine } \\ \text { 21-L-Cystathionine } & \text { 34. Ammonia } \\ \text { 22. L-lsoleucine } & \text { 35. Creatinine } \\ \text { 23. L-Leucine } & \text { 36. L-Ornithine } \\ \text { 24. L-Norleucine } & \text { 37. L-Lysine }\end{array}$

37. L-Lysine
38. L-Histidine

39. L-3-Methylhistidin

40. L-1-Methylhistidine

41. L-Carnosine

42. Anserine

43. L- $\alpha$-Amino- $\beta$ -

guanidinopropionic acid

44. L-Arginine
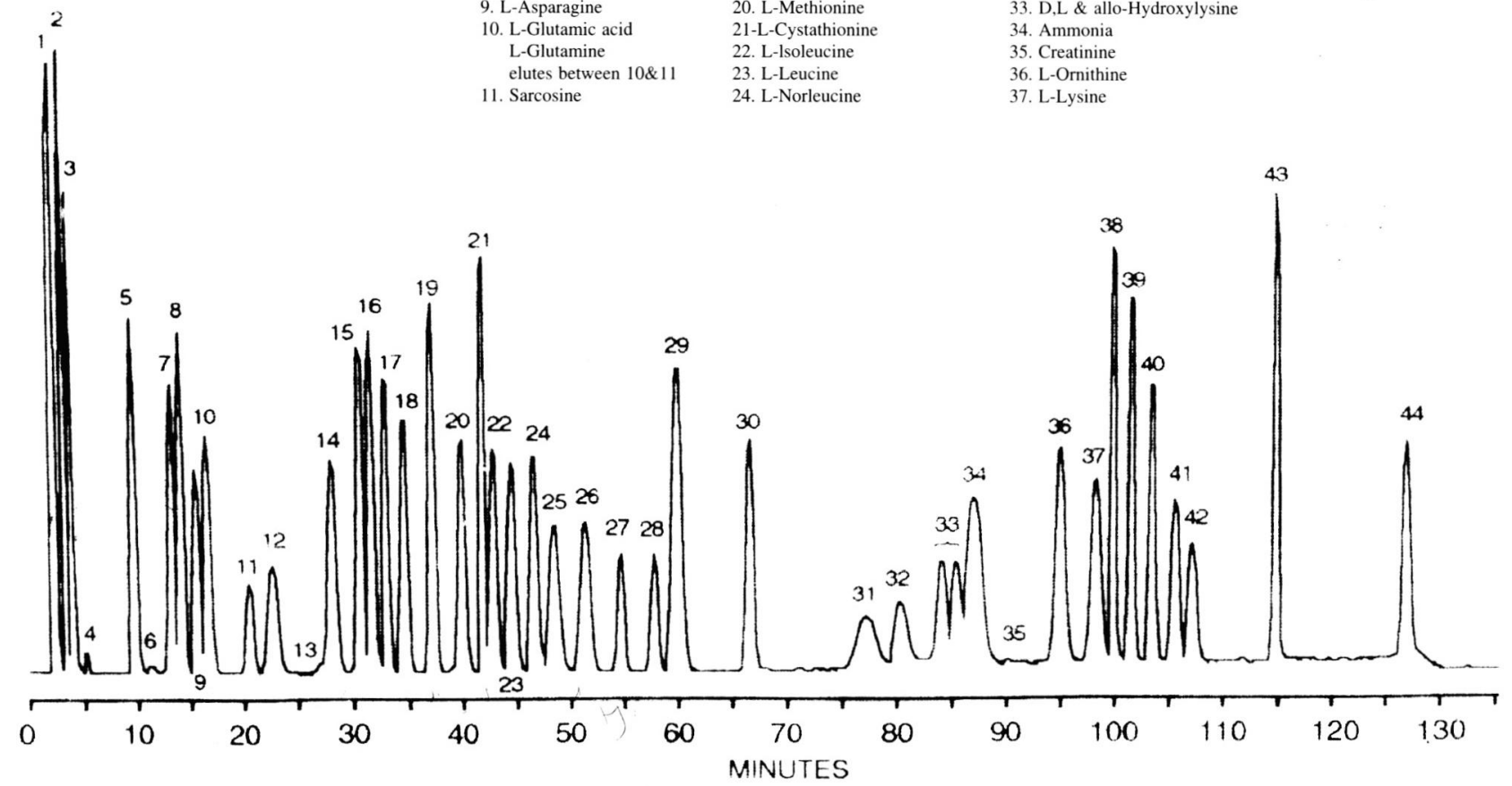

Fig. 1. - Peak identification and integration of amino acid standart ( 44 amino acid and related compounds) by cation-exchange HPLC using Li system.

\begin{tabular}{ccccccl}
\hline Step & (min) & $\begin{array}{c}\text { Time } \\
\text { Interval }\end{array}$ & $\mathbf{L i ~ 2 8 0}$ & $\begin{array}{c}\text { \% } \\
\text { Li 750 }\end{array}$ & $\begin{array}{c}\text { \% } \\
\text { RG003 }\end{array}$ & $\begin{array}{c}\text { \% } \\
\text { Comment }\end{array}$ \\
\hline Equil. & & 10 & 100 & 0 & 0 & Pre-run \\
0 & 0 & 0 & 100 & 0 & 0 & Inject \\
1 & $0-12$ & 12 & 100 & 0 & 0 & Isocratic \\
2 & $12-48$ & 36 & 65 & 35 & 0 & Linear gradient \\
3 & $48-90$ & 42 & 0 & 100 & 0 & Linear gradient \\
4 & $90-95$ & 5 & 0 & 100 & 0 & Isocratic \\
5 & $95-120$ & 25 & 0 & 94 & 6 & Linear gradient \\
6 & $120-130$ & 10 & 100 & 0 & 0 & Step change, \\
& & & & & & end \\
\end{tabular}

Column temperature: $40^{\circ} \mathrm{C}$. Eluent flow rate: $0.30 \mathrm{~mL} / \mathrm{min}$.

Table I. - HPLC Lithium gradient program for free amino acide analysis of physiological amino acid calibration standards (Sigma), cyst fluids of human, sheep, cattle and sera with hydatid patients.

samples of infected patients contained 11, 9, 12 and 19 free amino acids, respectively.

As seen in Table II, the levels of glycine, alanine, valine and tyrosine in fertile and infertile hydatid cyst fluids were significantly higher than that measured in sera of hydatid disease patient. The level of glycine, in particular, in the fertile cyst fluids was found to be significantly higher than that of infertile cyst fluids from either of sample materials which contained 2, 10 and 13 times less of glycine with respect to being from cattle, human and sera. Whereas alanine and valine concentrations in the fertile and infertile cyst fluids of sheep were not statistically significant, valine levels in fertile cyst fluids were about 12 times higher than that found in the fertile cyst fluids of human liver. Neither of free amino acid levels including tyrosine, citrulline, leucine, isoleucine and lysine were found to be significantly different in fertile and infertile hydatid cyst fluids (Table II). However, the levels of tyrosine, citrulline, leucine, isoleucine and lysine were all similar either in fertile or infertile cyst fluids. Free arginine levels in fertile (from sheep) and infertile (from human) cyst fluids were also similar, but it was not detected in infertile cyst (from cattle) fluids (Table II).

Table II also includes the levels of non-protein amino acids incluiding taurine, amino butyric acid and citrulline, and shows that taurine, amino butyric acid and citrulline levels in fertile and infertile cyst fluids were 40 times higher that that found in sera of hydatid patients. Taurine levels in fertile and infertile cyst fluids were about 11 times and 6-9 times higher, respectively, than that found in sera of hydatid cyst 


\begin{tabular}{|c|c|c|c|c|c|}
\hline \multirow[b]{2}{*}{ Amino acid } & \multirow[b]{2}{*}{$\begin{array}{c}\mathbf{R T}^{*} \\
\text { (minute) }\end{array}$} & \multicolumn{3}{|c|}{ Hydatid fluids } & \multirow[b]{2}{*}{$\begin{array}{c}\text { Sera (patient with } \\
\text { hydatid disease) (N: 3) } \\
\text { d }\end{array}$} \\
\hline & & $\begin{array}{c}\text { Fertile sheep } \\
\text { hydatid fluid (N: 10) } \\
\text { a }\end{array}$ & $\begin{array}{c}\text { Infertile cattle } \\
\text { hydatid fluid (N: 10) } \\
\text { b }\end{array}$ & $\begin{array}{l}\text { Infertile human } \\
\text { hydatid fluid (N: 3) } \\
\text { c }\end{array}$ & \\
\hline Taurine & 3.42 & $2.2 \pm 1.60$ & $1.28 \pm 0.46$ & $1.82 \pm 0.78$ & $0.18 \pm 0.12$ \\
\hline Aspartic acid & 8.09 & ND & ND & $0.12 \pm 0.08$ & ND \\
\hline Treonine & 11.94 & ND & ND & $0.72 \pm 0.34$ & $0.5 \pm 0.18$ \\
\hline Serine & 12.83 & ND & ND & ND & $0.9 \pm 0.44$ \\
\hline Asparagine & 14.31 & ND & ND & ND & $0.0042 \pm 0.00$ \\
\hline Glutamic acid & 15.23 & ND & ND & ND & $0.18 \pm 0.04$ \\
\hline $\begin{array}{l}\mathrm{D}, \mathrm{L}-\alpha-\mathrm{\alpha} \text {-Amino } \\
\text { atipic acid }\end{array}$ & 21.12 & $\mathrm{ND}$ & ND & $0.02 \pm 0.0$ & $0.02 \pm 0.0$ \\
\hline Glycine & 25.96 & $21.12 \pm 11.78$ & $11.66 \pm 10.2$ & $1.78 \pm 0.6$ & $1.64 \pm 0.82$ \\
\hline Alanine & 28.00 & $11.52 \pm 6.64$ & $16.26 \pm 9.96$ & $7.54 \pm 2.02$ & $1.1 \pm 0.2-32$ \\
\hline Citrulline & 29.17 & $3.92 \pm 2.48$ & $6.6 \pm 5.0$ & $4.54 \pm 2.72$ & $0.3 \pm 0.26$ \\
\hline $\begin{array}{l}\alpha \text {-Amino, } N- \\
\text { butyric acid }\end{array}$ & 30.30 & $2.54 \pm 1.64$ & ND & ND & $0.06 \pm 0.04$ \\
\hline Valine & 31.75 & $12.44 \pm 6.40$ & $13.66 \pm 5.36$ & $1.02 \pm 0.4$ & $3.08 \pm 2.96$ \\
\hline Cystine & 34.20 & ND & ND & ND & $0.06 \pm 0.04$ \\
\hline Isoleucine & 39.32 & $4.52 \pm 1.64$ & $5.94 \pm 2.40$ & $0.64 \pm 0.54$ & $0.24 \pm 0.20$ \\
\hline Leucine & 40.91 & $4.08 \pm 1.9$ & $5.44 \pm 2.24$ & $1.45 \pm 0.6$ & $0.24 \pm 0.06$ \\
\hline Tyrosine & 44.97 & $10.22 \pm 8.30$ & $13.24 \pm 5.24$ & $12.76 \pm 2.80$ & $0.18 \pm 0.10$ \\
\hline Phenylalanine & 48.08 & ND & ND & ND & $0.12 \pm 0.08$ \\
\hline Lysine & 94.38 & $0.50 \pm 0.26$ & $0.22 \pm 0.10$ & ND & $0.22 \pm 0.08$ \\
\hline Histidine & 99.56 & ND & ND & $0.72 \pm 0.42$ & $0.08 \pm 0.06$ \\
\hline Arginine & 125.92 & $3.12 \pm 1.6$ & ND & $3.981 \pm 2.26$ & $0.46 \pm 0.08$ \\
\hline
\end{tabular}

* RT : Retention time; N.D : Values not determined.

Taurine: a, d; b, d; c, d; P $<0.01$

Glycine: a, b; $\mathrm{P}<0.05$, a, c; a, d; b, c; b, d; P $<0.01$

Alanine: c, d; $\mathrm{P}<0.05, \mathrm{a}, \mathrm{d} ; \mathrm{b}, \mathrm{d} ; \mathrm{P}<0.01$

$\alpha$-amino, n-butyric acid: a, d; $\mathrm{P}<0.001$

Isoleucine: a, c; a, d; b, c; b, d; $\mathrm{P}<0.01$

Citrulline: $\mathrm{a}, \mathrm{d} ; \mathrm{b}, \mathrm{d} ; \mathrm{c}, \mathrm{d} ; \mathrm{P}<0.01$

Valine: a, c; b, c; $\mathrm{P}<0.01, \mathrm{a}, \mathrm{d} ; \mathrm{b}, \mathrm{d} ; \mathrm{c}, \mathrm{d} ; \mathrm{P}<0.05$

Leucine: a, c; b, c; P $<0.05$, c, d; P $<0.01$, a, d; b, d; P $<0.001$

Lysine: $\mathrm{a}, \mathrm{b} ; \mathrm{a}, \mathrm{d} ; \mathrm{P}<0.05$

Histidine: $\mathrm{c}, \mathrm{d} ; \mathrm{P}<0.01$

Arginine: a, d; c, d; P $<0.01$

Table II. - Free amino acid contents $(\mu \mathrm{mol} / \mathrm{ml}$ ) in cyst fluids of fertile (sheep liver), infertile (cattle liver), infertile (human liver) hydatid cysts and sera with hydatid patients.

patients. Citrulline content of fertile and infertile cyst fluids was similar, but its level was at least 12 times more concentrated than that of host sera.

\section{DISCUSSION}

$\mathrm{F}$ Tree amino acid compositions in the environment of the larval stage parasites have been extensively studied for Taenia bydatigena cysticercus (Pathak et al., 1980), Hymenolepis diminuta (Chappell \& Walker, 1980) and procercoids of Triaenophorus nodulosus, shark tapeworm Lacistorhynchus sp. (Barrett, 1981).

In a study, Hurd reported that 28 components were detected in the free amino acid pool of hydatid fluid from primary equine hydatid cysts, secondary equine cysts passaged to mice and gerbils, and from secondary ovine cysts passaged to gerbils (Hurd, 1989). Free amino acid concentrations in host plasma and cysts fluids were also analysed and compared with each other in his study which demonstrated that the free amino acids in hydatid fluid were higher than in the corresponding host plasma, but the host plasma free amino acid levels were not different at all between infected or uninfected animals. It has been stated that primary and secondary cysts clearly differ with respect to the free amino acid pool in hydatid fluid, and this difference may come from the nature of the host, location within the host, selective properties of germinal membrane as well as the age of host and age of cyst (Hurd, 1989). In several other studies, very high levels of glycine, alanine and valine amino acids in Cestodes have also been reported (Krvavica \& Asaj, 1959; Chappell \& Walker, 1980; Pathak et al., 1980; Hurd 1989).

In a search of medical literature we have found no data on the levels of free amino acids with particular reference to fertile cysts containing viable protoscolecces and infertile hydatid fluids. Our results showed that the levels of free amino acids in the fertile cyst fluids from sheep liver, infertile cattle and human hydatid cyst fluids and serum samples of infected patients contained 
11, 9, 12 and 19 free amino acids, respectively. This level of free amino acids we detected using HPLC with post-column derivatization system clearly is different from that reported by Hurd who detected 28 free amino acids and related components by HPLC cathionexchange system using fluorescence detection with Ophthaldialdeyde in pool of hydatid fluids from primary and secondary aquine cysts, secondary ovine cysts and host plasma (Hurd, 1989). This differences may therefore be due to the methods used to detect free amino acids.

All of the amino acid levels in fertile and infertile hydatid cyst fluids were found to be higher than that of infected human sera. Free amino acid profiles of hydatid fluids in our study resembles that of Hurd's results (Hurd, 1989) in the sense that cyst fluids in general contain higher amounts of free amino acids irrespective of being fertile or infertile cysts.

It has been shown that the concentrations of glucose, fatty acids, urea, electrolytes and mineral concentrations in the hydatid fluids are lower than that of host sera (Frayha \& Haddad, 1980 ; Barrett, 1981). It is very intriguing that the free amino acid contents of hydatid fluids are always higher than sera. It is equally interesting that amino acids maintain higher concentration despite their lower amounts in serum compartment. This condition of amino acid gradient may be provided by the germinal membrane's selective properties. Another interesting point is that except glycine, the levels of free amino acid in fertile and infertile cyst fluids are all similar which makes it hard to explain the direct metabolic relationship between the free amino acids present in cyst fluid and larval form of parasite.

Taurine, amino butyric acid and citrulline are non-protein amino acids, and they are not present in natural protein structures, mainly found as metabolic intermediates or in some cases as neurotransmitters. We detected $\alpha$-amino n-butric acid in fertile hydatid cyst fluids but not in the infertiles. It has been reported that amino butric acid is utilised as a donor in reactions of 2-oxoglutarate linked transaminases (Barrett, 1981). The finding that taurine, amino butric acid and citrulline concentrations in fertile cyst fluids are 40 times higher than that detected in sera of hydatid cyst patients suggests that they may be the end products of protoscolecces protein metabolism. Taurine and citrulline were also present in fertile and infertile cyst fluids.

Glycine and taurine often occur in high levels in the tissues of marine animals (Barrett, 1981). Like marine animals, protoscolecces live in fluids enclosed by germinal membrane, and this environment (cyst fluid) contains high levels of glycine, alanine and valine. Not only fertile cyst fluids but also infertile cyst fluids contain high levels of these amino acids. These amino acids most probably maintain the osmotic pressure in hydatid cyst fluids as it is explained for the larval stage of the trematode Himasthla quissetensis (Barrett, 1981).

\section{CONCLUSION}

Tn summary, by using post-column HPLC (pickering derivatization) system we have provided significant amount of information with regard to the presence of free amino acids as well as non-protein amino acids in fertile and infertile cyst fluids. The results showed that the total amounts of free amino acids in fertile (from sheep), infertile (from cattle) and infertile (from human) hydatid cyst fluids including sera of hydatid cyst patients were $76 \mu \mathrm{mol} / \mathrm{ml}, 74 \mu \mathrm{mol} / \mathrm{ml}$, $37.1 \mu \mathrm{mol} / \mathrm{ml}$ and $10.7 \mu \mathrm{mol} / \mathrm{ml}$, respectively. Total amount of free amino acids content in fertile and infertile cyst fluids were about three to eight times higher than that found in human sera with hydatid patients. Taken together the variations of the levels of free amino acids found in between fertile and infertile cyst fluids and also in the serum compartment of hydatid patients, the significance of free amino acid pool for hydatid amino acid metabolism remains obscure and warrants further studies to clarify the implications of differential concentration of some amino acids in hydatid fluids.

\section{REFERENCES}

Alkarmi T.O., Ali-Khan Z. \& Zarkadas C.G. Characterization of amiloid protein from mice infected with alveolar hydatid cyst : Isolation, purification, and amino acid composition. Experimental and Molecular Pathology, 1986, 45, 142-159.

Barrett J. Biochemistry of Parasitic Helminths. Macmillan Publishers Ltd. London and Basingstoke, 1981, 41-56.

Chappell I.H. \& Walker E. Studies on the free pool of amino acids of the Cestode Hymenolepis diminuta. Parasitology, 1973, 67, 289-305.

ÇELIK C. The urea biosynthesis in hydatid cyst of Echinococcus gramulosus. Doga-Tr. Journal of Veterinary Medical Sciences, 1986, 39, 537-541.

ÇELıK C. Studies on pyrimidine biosynthesis in hydatid cysts (protoscolecces of E. granulosus). Doga-Tr. Journal of Veterinary Medical Sciences, 1987, 11, 7-13.

FRAYHA G.J. \& HADDAD R. Comparative chemical composition of protoscolecces and hydatid cyst fluid of Echinococcus granulosus (Cestoda). International Journal for Parasitology, 1980, 10, 359-364.

HURD H. Echinococcus granulosus: a comparison of free amino acid concentration in hydatid fluid from primary and secondary cysts and host plasma. Parasitology, 1989, 98, 135-143. 
Krvavica S., Martincic T. \& Asaj R. Metabolism of amino acids in some parasites II. Amino acids in the hydatid fluid and germinal layer of Echinococcus. Veterinarski Archiv, 1959, 29, 314-321.

MCManus D.P. A biochemical study of adult and cystic stages of Echinococcos granulosus of human and animal origin from Kenya. Journal of Helminthology, 1981, 55, 21-27.

McManus D.P. \& SMYTH J.D. Differences in the chemical composition and carbohydrate metabolism of Echinococcus granulosus (horse and sheep strain) and E. multilocularis. Parasitology, 1978, 77, 103-109.

Njeruh F.M., Gathura P.B. \& Gathuma J.M. Application of enzyme-linked immunosorbent assay (ELISA) based on two E. granulosus antigens in the diagnosis of human hydatidosis. The East African Medical Journal, 1989, 66, 738-742.

PathaK K.M.L., Gaur S.N.S. \& Verma H.C. Quantitative estimation of amino acids in cysticercus of Taenia bydatigena. Veterinary Parasitology, 1980, 7, 375-378.

PICKERING M. Ion-exchange chromatography of free amino acids. LC.GC, 1989, 7 (6), 484-490.

Pickering Laboratories. HPLC post-column derivatization. Instruments columns methods chemicals reagents. Profuct Catolog. p. 37. CA, USA, 1995-1996.

ÖZEn N., ÇELIK C. \& ÖZKAN K. Trace elements in hydatid disease. J. Trace. Elem. Electrolites Health Dis., 1992, 6, 6770 .

Reçu le 29 décembre 2000 Accepté le 11 mai 2001 